\title{
APPLICABILITY OF THE FOURTH AMENDMENT IN CIVIL CASES*
}

\author{
LOUIS J. DEREUIL $\nmid$
}

$T_{\text {person accused of crime the right to a fair and impartial trial }}^{\text {HE CONSTITUTION of the United States guarantees to every }}$ by jury. Under this guarantee, the fourth amendment ${ }^{1}$ to the Constitution protects citizens from unreasonable searches and seizures ${ }^{3}$ and permits them the right to be secure in their homes, papers and effects from such searches and seizures.

Protection of the basic rights of the individual from both oppres-

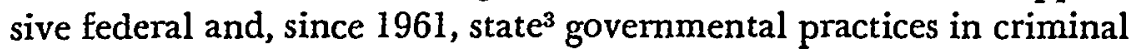
proceedings stems from the fourth amendment. The traditional role played by the fourth amendment in criminal proceedings is unquestioned. ${ }^{4}$ Applicability of its protective principle outside the ambit of the criminal law, however, remains open to inquiry. It is the purpose of this paper to examine generally the extension of the role of the fourth amendment to both original and collateral civil tax proceedings and to measure in particular its effect upon the admissibility of evidence in civil tax proceedings, upon the enforcement of a section $7602^{\circ}$ civil administrative summons, and upon the validity of certain federal civil tax assessments and forfeiture proceedings. A

- The views expressed are the author's and should not be considered as being the opinion of the Treasury Department, the Internal Revenue Service, or the Chicf Counsel's Office.

†B.B.A. 1954, LL.B. 1954, Tulane University; LL.M. 1958, George Washington University; Attorney, Office of Chief Counsel, Atlanta Region, Internal Revenue Scrvice.

1 "The right of the people to be secure in their persons, houses, papers, and effects, against unreasonable searches and seizures, shall not be violated, and no warrants shall issue, but upon probable cause supported by oath or affirmation, and particularly describing the place to be searched, and the persons or things to be seized." U.S. ConsT. AMEND. IV.

'Rules 4 and 41 of the Federal Rules of Criminal Procedure set forth the requirements for the issuance of warrants for arrest and search. A search warrant may be issued only upon a sworn affidavit showing probable cause and describing the person or place to be searched, and it can apply only to property stolen, embezzled, or used or intended for use in the commission of crime.

Mapp v. Ohio, 367 U.S. 643 (1961).

- Varon, Search, Seizures and Immunities (1961); Traynor, Mapp. i. Ohio al l.arge in the Fifty States, 1962 Duke L.J. 319; Avakian, Searches and Seizures, Y.Y.1;. 17тu INST. ON FED. TAX 531 (1959).

${ }^{\circ}$ INT. REV. CODE OF 1954. 
prior cursory review of the historical role enjoyed by the fourth amendment in criminal proceedings will assist in placing in proper perspective the relatively new and expanding course taken by it in civil proceedings.

\section{Criminal Proceedings-Background}

While unreasonable searches and seizures are prohibited by the fourth amendment to the Constitution, it should be noted that it does not expressly bar the admission in criminal proceedings of evidence obtained unlawfully. ${ }^{6}$ At common law, the admissibility of evidence was not affected by the means through which it was obtained. This rule presently controls the admission of illegally obtained evidence, except in cases where evidence is secured by violating the fourth amendment, wire-tapping, ${ }^{8}$ or by a coerced confession or by violence or unusually long and illegal detention. ${ }^{9}$ It is by judicial interpretation of the scope of the mandate of the fourth amendment, rather than its specific proscriptions, that such evidence is excluded from federal criminal proceedings. ${ }^{10}$ Exclusion is the only practical way of enforcing the constitutional protection. ${ }^{11}$

As a matter of historical interest, it may be observed that the Supreme Court of the United States in the case of Boyd v. United States $^{12}$ early alluded to the possibility that the admission of the illegally secured evidence was violative of the guarantees contained in the fourth amendment to the Constitution. The Court thereafter, in Weeks $v$. United States, ${ }^{13}$ adopted the federal exclusionary rule by which federal courts excluded from consideration any and all evidence illegally seized by federal officers. Thus, Weeks supplied "teeth" to the fourth amendment, making it a rule of evidence.

\footnotetext{
- Shinyu Noro v. United States, 148 F.2d 696 (5th Cir.), cert. denied, 326 U.S. 720 (1945).

78 WIGMORE, EvideNce $\S 2183$ (McNaughton rev. 1961); 20 AM. JuR. Evidence, $\$ 393$ (1939).

848 Stat. 1109 (1934), 47 U.S.C. $\$ 605$ (1958); Nardone v. United States, 308 U.S. 338 (1939).

- Wilson v. United States, 162 U.S. 613 (1896).

${ }^{10}$ United States v. Jeffers, 342 U.S. 48 (1951); 8 Wigmore, Evidence $\$ 2184$ (McNaughton rev. 1961).

${ }_{11}$ United States v. Pugliese, 158 F.2d 497 (2d Cir. 1945).

12116 U.S. 616 (1886).

18232 U.S. 383 (1914).
} 
The Weeks opinion went on to say, however, that this exclusionary rule of evidence did not bind state officers in pursuit of their police activities.

This limitation carried with it an attendant evil. Federal officers, in order to obviate the requirement of procuring a search warrant, would enlist the assistance of a state officer who would then procure evidence in a wrongful or illegal fashion. Such evidence, under the Weeks case interpretation, would be admissible in federal court prosecutions. The employment of such unfair tactics led to the evolution of the "participation doctrine." Where overt participation between state and federal authorities was established, such evidence, procured as a result of an illegal search and seizure was excluded in federal court prosecutions. ${ }^{14}$ The trend toward constitutional protection was extended in Rea $v$. United States ${ }^{15}$ which held that evidence illegally seized and suppressed in federal court could not be turned over to state authorities for state prosecution on the theory that federal courts had the right of exercise of authority over their own officers.

In Wolf $v$. Colorado, ${ }^{18}$ the Supreme Court held that in a prosecution in a state court for a state crime, the fourth amendment prohibits unreasonable searches and seizures by state officers but that the due process clause of the fourteenth amendment did not forbid the admission of relevant evidence even though obtained by an unreasonable search and seizure. Thus, in Wolf the Supreme Court decided that the Weeks exclusionary rule would not be imposed upon the states which were free to admit or exclude such evidence.

Where state officers made a search and seizure not for the purpose of aiding in prosecution of the federal offense, the results of said seizure, however procured, could then be turned over to federal authorities for prosecution in the federal courts. ${ }^{17}$ Where evidence was improperly obtained by state officers and presented on a silver platter to federal officials for use in a federal prosecution, some courts held such evidence admissible and other courts held it inadmissible. ${ }^{18}$

\footnotetext{
14 Lustig v. United States, 338 U.S. 74 (1949) (state activities participated in by federal officer); Gambino v. United States, 275 U.S. 310 (1927) (state officers acting on behalf of federal officers); Byars v. United States, 273 U.S. 28 (1927) (joint participation by state and federal officers).

15350 U.S. 214 (1956).

16338 U.S. 25 (1949).

Ir United States v. Haywood, 208 F.2d 156 (7th Gir. 1953).

${ }^{18}$ Compare West v. United States, 259 F.2d 868 (5th Gir. 1958), and Graham v.
} 
The difference in federal interpretations concerning the silver platter doctrine was ultimately decided by the Supreme Court of United States in Elkins $v$. United States ${ }^{19}$ in which the Court, in overruling Weeks, repudiated the silver platter doctrine where evidence legally obtained by state officers without federal participation or cooperation was held inadmissible in a federal court prosecution.

In the recent revolutionary decision of Mapp $v$. Ohio, which amplified the Wolf rule that the fourteenth amendment incorporated the fourth amendment, the Supreme Court held that all evidence obtained by search and seizure by state officials in violation of the fourth amendment is inadmissible in a criminal trial in the state court. Thus, Mapp put "teeth" in the fourteenth amendment by requiring extension of the federal exclusionary rule to the states. The law is now well established that any and all evidence procured by either state or federal officials ${ }^{20}$ as a result of an illegal or unreasonable search and seizure in violation of the constitutional rights of an accused is inadmissible in a criminal trial in a federal or state court inasmuch as the federal exclusionary rule is now an essential part of both the fourth and fourteenth amendments. ${ }^{21}$

\section{II}

\section{Original Givil Tax Proceedings}

\section{A. Enforcement of Section 7602 Summons- Theory of Probable Cause}

It has been seen that in a criminal proceeding the fourth amendment affords protection against an actual search and seizure of an individual's premises which has been found to be unreasonable. On the other hand, the determination of the fourth amendment's

United States, 257 F.2d 724 (6th Cir. 1958), with Hanna v. United States, 260 F.2d 723 (D.C. Cir. 1958) (fourth amendment held applicable to state officers through fourteenth amendment).

${ }^{30} 364$ U.S. 206 (1960).

${ }^{20}$ Evidence procured by a non-governmental third-party still is admissible, Geniviva v. Bingler, 206 F. Supp. 81 (W.D. Pa. 1961) (protection of fourth amendment applies only against governmental agencies and their employees and not to the acts of private individuals).

${ }^{32}$ Evidence obtained in violation of an individual's rights under the fourth amendment may be objected to at the trial, Gouled v. United States, 255 U.S. 298 (1921), or, prior to the trial, the defendant may move for suppression of the illegally seized evidence pursuant to Rule 41 (e) of the Federal Rules of Criminal Procedure which provides a method for enforcing the protection against an unreasonable search and seizure guaranteed by the fourth amendment. In re Bodkin, 165 F. Supp. 25 (E.D.N.Y. 1958); United States v. Lipshitz, 132 F. Supp. 519 (E.D.N.Y. 1955). 
proper function in the requirement, through an administrative summons or subpoena of the production of one's books and records, a figurative or constructive search, requires further examination. More particularly, may a taxpayer or third party assert the applicability of the fourth amendment during the course of a federal tax investigation on the basis that an administrative summons or subpoena duçes tecum issued him is oppressive, unreasonable, broad and inquisitorial, and therefore in violation of his rights under the fourth amendment?

The ability of the Internal Revenue Service to investigate is essential to the proper determination, assessment and collection of taxes. Congress has provided the Internal Revenue Service with power and authority to require testimony and the production of books and records for the purpose of ascertaining the correctness of the return or determining or collecting the tax liability. ${ }^{22}$ Section 7603 of the Internal Revenue Code of 1954 provides for the issuance of the summons ${ }^{23}$ and contains the requirement that the books and papers must be described "with reasonable certainty." Sections 7604 and 7402 (b) of the Code empower the United States District Court ${ }^{24}$ for the district in which the person resides to enforce the subpoena by requiring obedience to the summons under penalty of punishment for contempt for refusal to do so. The only limitations written into the statute are the provisions in section 7605 that the time and place of examination must be "reasonable under the circumstances"; that the date for appearance before the agent shall be not less than ten days from the date of the summons; and that no taxpayer shall be subjected to unnecessary examination or investigations, and only one inspection of a taxpayer's books of account shall be made for each taxable year, unless the taxpayer requests otherwise or the Secretary or his delegate, after investigation, notifies the taxpayer in writing that an additional inspection is necessary.

While the provisions of the Internal Revenue Code relating to examination and inspection of returns are silent for the most part as to the right of the taxpayer to refuse the agent's request for exam-

\footnotetext{
22 INT. Rev. CODE OF 1954, \$7602.

is Rev. Pro. 55-6, 1955-2 Cum. BuLl. 903, sets forth the procedure for use, issuance and enforcement of summons in accordance with the provisions of the Internal Revenue Code of 1954 .

24 The Federal Rules of Civil Procedure apply on the hearing of the petition. Martin v. Chandis Securities Co., 128 F.2d 731 (9th Cir. 1942).
} 
ination of his papers, it is to be noted that these statutory provisions are limited by the Constitution and in particular by the fourth and fifth amendments.

An administrative summons has been held analogous to a grand jury subpoena ${ }^{25}$ and equivalent to a search and seizure ${ }^{28}$ on the theory that a compulsory production of one's private papers to establish a criminal charge against him or to forfeit his property is within the scope of the fourth amendment in all cases in which a search and seizure would be. Thus, constitutionality requires that a subpoena equivalent to a search and seizure must be a reasonable exercise of the inquisitorial power. ${ }^{27}$

A federal tax investigation normally is controlled by the codal provision which provides that the period of limitations within which a statutory tax assessment may be made against a taxpayer is three years after the return is filed;28 however, in cases of an unlawful attempt in any manner to defeat or evade tax, assessment and/or collection may proceed at any time. ${ }^{29}$

Prior to an investigation of barred years, the government, under certain circumstances, has been required to show a probability of fraud. Such a requirement is generally referred to as a showing of probable cause and the concept is called the probable cause theory. The requirement of proof of probable cause necessary to open timebarred years to investigation seemingly is based on the grounds either that the examination is necessary as required by section 7605 (b) of the Internal Revenue Code of 1954 or that otherwise the privilege against unlawful search and seizure granted by the fourth amendment would be violated.

Section 7605 (b) of the Internal Revenue Code of 1954, which provides that no taxpayer shall be subject to unnecessary examina-

\footnotetext{
35 United States v. Morton Salt Co., 338 U.S. 632 (1950).

${ }^{20}$ Boyd v. United States, 166 U.S. 616 (1886) (compulsory production of individual's business invoices to be used as evidence against him in quasi-criminal proceeding to forfeit his property for alleged fraud against the federal custom laws, held administrative process was an unreasonable search and seizure).

${ }^{87}$ Hale v. Henkel, 201 U.S. 43 (1906) (subpoena duces tecum requiring production of all books and papers of a corporation may be so onerous as to constitute an unreasonable search).

${ }^{38}$ INT. Rev. CODE OF 1954, §6501 (a).

${ }^{20}$ INT. Rev. Cone of $1954, \S \S 6501$ (c) (1), (2). Thus, where the statute of limitations for assessment of the tax has expired, the production of taxpayer's books and records may not be ordered, Farmers' \& Mechanics' Nat'l Bank v. United States, 11 F.2d 348 (3d Cir. 1926), except where the statute is open because of a false or fraudulent return or failure to file a return.
} 
tions, has been interpreted by the Court of Appeals for the First Circuit as requiring a showing of probable cause before closed years may be open to investigation. ${ }^{30}$ The First Circuit accordingly ordered a taxpayer to comply with a subpoena duces tecum as regards closed tax years where there was a showing of a reasonable belief of fraud..$^{31}$ Similarly, section 7605 (b) has been interpreted as requiring a showing of probable cause by the Ninth Gircuit in Martin $v$. Chandis Securities Co. ${ }^{32}$ and more recently in Boren v. Tucker. $^{33}$

In a petition seeking enforcement of a summons relative to barred years, however, the Second Circuit appears to have rejected the probable cause theory on the ground that the examination is not unnecessary or unreasonable within the meaning of section 7605 (b) merely because the years under investigation are barred. ${ }^{34}$ This view appears consistent with the position earlier taken by the Second Gircuit that an investigation is not "unnecessary" under section 7605 (b) even though facts are not alleged which indicate the probable cause for the investigation. ${ }^{35}$

The Gourt of Appeals for the Sixth Circuit appears to be of the view that no showing of probable cause is required in that all that is required is an allegation or showing of suspicion of fraud without the necessity of delving into the basis of that suspicion. ${ }^{36}$ Similarly, the Fifth Circuit appears to have adopted the view that proof of probable cause is not required in that the allegation of facts to

${ }^{30}$ O'Connor v. O'Connell, 253 E.2d 365 (1st Cir. 1958) (subpoena dismissed where failure to show that a reasonable basis existed for a suspicion of fraud or that there was probable cause to believe that the taxpayer was guilty of fraud in a statute-barred year).

${ }^{31}$ Lash v. Nighosian, 273 F.2d 185 (Ist Cir. 1959), cert. denied, 362 U.S. 904 (1960).

32128 F.2d 731 (9th Cir. 1942).

${ }^{33} 239$ F.2d 767 (9th Cir. 1956) (held, there was a sufficient showing of the possibility of fraud to permit the inquiry into the matter and to require production of the records sought).

s4 Foster v. United States, 265 F.2d 183 (2d Cir.), cert. denied, 360 U.S. 912 (1959).

86 United States v. Carroll, 246 F.2d 762 (2d Cir.), cert. denied, 355 U.S. $85 T$ (1957) (government need not allege nor show grounds for questioning whether taxpayer was resident of Germany prior to his being required to produce records for the year involved); United States v. United Distillers Prods. Corp., I56 F.2d 872 (2d Cir. 1946) (bona fide government suspicion of fraud required taxpayer to respond to subpoena duces tecum with respect to barred tax years).

${ }^{86}$ Eberhart v. Broadrock Dev. Corp., 296 F.2d 685 (6th Cir. 1961): Corbin Deposit Bank v. United States, 244 F.2d 177 (6th Cir. 1957); Peoples Deposit Bank \& Trust Co. v. United States, 212 F.2d 86 (6th Cir.), cert. denied, 348 U.S. 838 (1954) (government agent not obliged to disclose in detail the facts relative to fratd features of his investigation). 
reasonably justify a suspicion of fraud is not required.$^{37}$ The Third Circuit appears to require an allegation of fraud or at least a suspicion thereof to show that the investigation is necessary. ${ }^{38}$

It is seen that the federal circuit courts are in conflict over the question of whether proof of probable cause is required by section 7605 (b) of the Internal Revenue Code of 1954 in the enforcement of an administrative summons incident to a civil tax investigation. Similarly, uncertainty reigns over the question whether proof of probable cause is required by the fourth amendment.

Where a section 7602 summons was directed to the taxpayer, invocation of the fourth amendment was permitted to protect his books from a second examination where the tax year was barred and no suspicion of fraud was shown. ${ }^{39}$ Application of the fourth amendment appears to have rested on the practical consideration that where a taxpayer has duly made his return and paid the tax, and the statutory time limit for further assessment has expired, there should be no further required examination unless there is prima facie some good reason therefor. While the procedure sought, testimony under oath with reference to books and records, was not literally a search and seizure proscribed by the fourth amendment, the court in Andrews and Brooklyn Pawnbrokers interpreted the fourth amendment as imposing upon it a duty to protect the citizen against unreasonable and oppressive, inquisitorial investigations instituted and conducted without probable cause.

The Second Circuit, however, does not interpret the fourth amendment as requiring an advance showing that the underlying tax liability is not time-barred. ${ }^{40}$ In ordering a bank to comply with an Internal Revenue Service summons to produce records of the taxpayer with respect to barred years, the Second Circuit in Foster observed that an examination is not unnecessary or unreasonable within the meaning of the fourth amendment merely because any period of time has elapsed since the tax return was filed. Since the examination provided by section 7602 is to determine the

\footnotetext{
${ }^{37}$ Globe Construction Co. v. Humphrey, 229 F.2d 148 (5th Cir. 1956) (allegations of fraud in agent's affidavit held sufficient).

${ }^{38}$ Zimmerman v. Wilson, 81 F.2d 847 (3d Cir. 1936).

${ }^{39}$ In re Andrews' Tax Liability, 18 F. Supp. 804 (D. Md. 1937) (protective principle of fourth amendment not limited to criminal proceedings but extended to civil proceedings as well). See also In re Brooklyn Pawnbrokers, Inc., 39 F. Supp. 304 (E.D.N.Y. 1941) (taxpayer entitled to be free from unreasonable harassment).

${ }^{\circ}$ Foster v. United States, 265 F.2d 183 (2d Cir.), cert. denied, 360 U.S. 912 (1959).
} 
liability of any person for any internal revenue tax, the Second Circuit would interpret the constitutional immunity from unreasonable searches as not relieving a citizen of his testimonial duty to disclose information needed for the just and proper discharge of the governmental investigative functions.

It is submitted that the Foster interpretation of the role of the fourth amendment as not requiring a showing of probable cause represents a more meaningful and correct analysis of the problem involved. In any event, and under no circumstances is the government required to prove fraud.

Section 7602 (2) of the Internal Revenue Code of 1954 enables the Commissioner of Internal Revenue to examine third parties and authorizes him to require the production of books and papers material to the taxpayer's returns. The majority of decisions here involved third-party banking institutions which are subpoenaed to produce records of deposits and withdrawals of the taxpayer. It is settled that the taxpayer lacks standing to object to an enforcement order issued against the bank as a search or seizure forbidden by the fourth amendment since the taxpayer lacks a proprietary interest in the records. ${ }^{41}$

The bank, on the other hand, has been permitted to resist a subpoena duces tecum as constituting an unreasonable search where the search is out of all proportion to the end sought. ${ }^{42}$ In other cases, however, the bank must comply with a summons determined to be reasonable in absence of a showing that the subpoena was oppressive, unreasonable, or unnecessary. ${ }^{43}$ The rationale of these cases appears to be that the fourth amendment, where applicable, at most guards against abuse only by way of too much indefiniteness or breadth in the things required to be particularly described.44

4 Foster v. United States, supra note 40; People's Deposit Bank \& Trust v. United States, 212 F.2d 86 (6th Cir.), cert. denied, 348 U.S. 838 (1954); Zimmerman v. Wilson, 105 F.2d 583 (3d Cir. 1939); McMann v. SEC, 87 F.2d 377 (2d Cir.), cert. denied, 301 U.S. 684 (1937) (customer held not entitled to prevent broker from complying with subpoena issued by SEC to produce copy of customer's account); In re Upham's Income Tax, 18 F. Supp. 737 (S.D.N.Y. 1937).

12 First Nat'l Bank v. United States, 160 F.2d 532 (4th Cir. 1947) (subpoena requiring bank to produce six million items for inspection and run them on recordak machine held unreasonable); United States v. Third Northwestern Bank, 102 F. Supp. 879 (D. Minn. 1952) (summons required bank to examine 58,577 different items where taxpayer may have had only one transaction).

'3 People's Deposit Bank \& Trust Co. v. United States, 212 F.2d 86 (6th Gir.), cert. denied, 348 U.S. 838 (1954).

«4 See Oklahoma Press Publishing Co. v. Walling, 327 U.S. 186 (1946). 
Thus, it is seen that the question is whether the description of the records to be produced is so broad as to amount to an unreasonable search and seizure. An attorney successfully raised the bar of the fourth amendment in resisting a subpoena duces tecum which required the production before a grand jury of all his books, records, files, log books, memoranda, correspondence and other documents for a term of ten years. ${ }^{45}$ An accountant's plea of unreasonableness under the fourth amendment was held unfounded and a contempt order affirmed where a subpoena duces tecum required that the accountant provide the grand jury with the names of taxpayers appearing on copies of twenty-five tax returns in his office. ${ }^{46}$

Reliance on the fourth amendment has not been limited to matters relative to the determination of the proper tax liability. The bar of the fourth amendment has been raised, unsuccessfully, in collection matters in Jarecki $v$. Whetstone $e^{47}$ wherein the government brought suit to enforce an Internal Revenue subpoena duces tecum issued to the taxpayer to appear with her books and records disclosing her financial condition and to testify with respect to collection of her 1944 income tax liability. The court, however, noting that the fourth amendment is to be applied to protect a citizen against an oppressive, unreasonable and inquisitorial investigation, denied taxpayer's motion to dismiss the subpoena duces tecum on the ground that it violated the fourth amendment inasmuch as nothing was contained in the terms of the summons which violated her constitutional guarantees.

It can be seen from the foregoing that under certain narrow circumstances an aggrieved party during the course of a federal tax investigation may contest the enforcement of an Internal Revenue Service subpoena on either codal grounds where the examination is unnecessary within the meaning, of section 7605 (b) of the Internal Revenue Code of 1954 or upon constitutional grounds where the investigation is oppressive, unreasonable, inquisitorial and out of all proportion to the end sought as violative of the searches and seizures provisions of the fourth amendment. This right of an aggrieved

15 Schwimmer v. United States, 232 F.2d 855 (8th Cir. 1956).

to Donnelly v. United States, 201 F.2d 826 (9th Cir. 1953). See Broadrock Dev. Corp. v. Director of Internal Revenue, 283 F.2d 872 (6th Cir. 1960), wherein a corporate taxpayer's motion to quash a summons issued under $\$ 7602$ for production of its books and records as being too broad and therefore in violation of the fourth amendment was rejected as lacking in substance.

${ }^{17} 82$ F. Supp. 367 (N.D. Ill. 1948). 
party in a civil proceeding somewhat parallels the right of a defendant to raise the applicability of the fourth amendment in a criminal proceeding.

\section{B. Validity of Civil Tax Assessment as Affected by Fourth Amendment}

It has been seen that the fourth amendment plays a limited role in resisting an administrative subpoena incident to the determination of a civil tax liability and assessment. An interesting current question in need of resolution is whether a taxpayer may contest an existing civil tax assessment as illegal where the evidence upon which the civil tax liability was determined has been suppressed in a related criminal proceeding under the federal exclusionary rule as violative of the fourth amendment's prohibition against unreasonable searches and seizures.

A number of judicial decisions have been cited for the proposition that the federal exclusionary rule of the fourth amendment applies to civil cases. In the early case of Silverthorne Lumber Co., Inc. v. United States, ${ }^{48}$ a writ of subpoena was rendered invalid because in framing it the government used evidence earlier obtained in violation of the fourth amendment. Therein, while the defendants were under arrest on an indictment, officers of the United States without right or authority seized defendant's books, papers, and documents. The originals were ultimately ordered returned but a new indictment was prepared against the defendants based upon the knowledge the government agents had obtained in the original illegal search. A subsequent government subpoena for the production of the original records was issued and the lower court ordered defendants in contempt for failure to honor the subpoena. On appeal, the contempt order was reversed by the Supreme Court of the United States on the ground that the government could not use knowledge that it had illegally gained by seizure of the original papers "to call upon the owners in a more regular form to produce them"; that, if it could, it would be to "reduce the fourth amendment to a form of words"; and that the essence of a provision forbidding the acquisition of evidence in a certain way is that not merely evidence so acquired shall not be used before the Court "but that it shall not be used at

${ }^{48} 251$ U.S. 385 (1920). 
all." The Court further noted that knowledge gained by the government's own wrong cannot be used by it in the way proposed.

The Silverihorne case stands for the proposition that a writ of subpoena prepared for use in a subsequent criminal action is invalid because of the use in framing it of evidence ordered returned by reason of an illegal search and seizure in an earlier criminal proceeding. The Court of Appeals for the First Circuit in Rogers v. United States, ${ }^{49}$ relying on Silverthorne, interpreted the Silverthorne phrase "but that it shall not be used at all" to render invalid a civil judgment in the procurement of which evidence illegally obtained was used. Therein the government instituted a civil action in assumpsit to recover certain duties on foreign imported liquors imposed under the Tariff Act and recovered judgment against defendant. On appeal, the defendant's first assignment of error related to admission in evidence of certain liquors imported by Rogers which the government seized as the result of an unlawful search. Rogers made application to the district court for an order directing that the liquor be returned for the reason that it was seized illegally. The district court held the search warrant illegal and ordered the property seized returned, which was done. In the government's subsequent civil suit in assumpsit for the custom duties, the government was allowed, over objection, to introduce evidence much of which had been illegally obtained. The district court ruled that the evidence was admissible, that this was a suit of a "civil nature ... and that such evidence is admissible in a civil suit," though not in a criminal one, and the defendant excepted. Relying on Silverthorne, the First Circuit reversed and rendered invalid the civil judgment as based on evidence illegally seized in violation of the fourth amendment.

The case of Tovar $v$. Jarecki $i^{50}$ is also in point. Therein, the taxpayer instituted suit to enjoin and restrain the collection from him of a special marijuana tax assessed at the rate of $\$ 100.00$ per ounce under section 2590 (a) (2) of the Internal Revenue Code of 1939, claiming the tax assessment was illegal because the evidence acquired by illegal search and seizure upon which the tax was based had been suppressed in a related criminal case in which he was named defendant. In the injunction suit, the court observed that 
if the assessment had been based solely upon evidence obtained by the government by the unlawful search and seizure, and which evidence was before the court in the related criminal case, it would be required to hold the tax illegal and grant the relief prayed. The plaintiff, however, did not prevail inasmuch as he failed to prove that the officer who made the assessment acted upon evidence which had previously been ordered suppressed.

The principle of law that evidence obtained by the government in violation of a person's rights secured by the fourth amendment is not admissible against him in a criminal proceeding has been extended to other types of civil cases as well..$^{51}$

In view of the foregoing, it would seem that the fourth amendment could be utilized to permit a taxpayer to contest an existing civil tax assessment under the narrow circumstances where (1) a court in the related criminal proceeding has quashed the search warrant and suppressed the evidence seized at the raid and ordered it returned; (2) the indictment based on such evidence has been dismissed; (3) the government's libel of information has been dismissed and all property seized ordered retumed; and (4) there exist no records or other evidence other than those illegally seized and ordered returned from which the government could make a civil tax determination. ${ }^{52}$

\section{III}

\section{Collateral Civil Proceedings}

\section{A. Forfeiture Proceedings as Affected by Fourth Amendment}

In cases where evidence is suppressed in the criminal proceeding because of an illegal search and seizure, should the money or property be returned to the accused because the arrest, search and seizure is illegal? Pursuant to Rule 41 (e) of Federal Rules of Criminal Procedure, the accused may move for the return of the property illegally

\$2 United States v. Physic, 175 F.2d 338 (2d Cir. 1949) (cvidence suppressed because of illegal search held not admissible in civil forfeiture suit). See also Bolger v. Cleary. 293 F.2d 368 (2d Cir. 1961) (dissenting opinion); Schenck v. Ward, 24 F. Supp. 776 (D. Mass. 1938) (deportation proceeding); Ex parte Jackson, 263 Fed. 110 (D. Mont. 1920) (evidence based upon illegal search and seizure held not admissible in civil deportation proceedings).

¿2 Compare Reineman v. United States, 301 F.2d 267 (7th Cir. 1962), wherein a civil tax assessment was ruled invalid where based on a second inspection of taxpayer's books of account made without giving taxpayer prior written notice as required by $\$ 7602(\mathrm{~b})$ of the InTERnat Revenue CODE of 1954. 
seized. The mere fact, however, that property is illegally seized from the possession of the aggrieved person does not necessarily require its return inasmuch as the fourth amendment does not irrevocably guarantee that illegally seized property will be returned to its owner. ${ }^{63}$ This rule applies particularly to contraband property or property forfeitable or subject to lien or libel. ${ }^{54}$

Following commencement of an information against him for violation of the federal excise-wagering tax laws, taxpayer's motion pursuant to Federal Criminal Rule 41 (e) to suppress evidence (cash, automobile) was granted, but taxpayer's subsequent action to recover evidence illegally seized pursuant to fourth amendment was dismissed in Field $v$. United States ${ }^{55}$ and Carlo $v$. United States. ${ }^{58}$ In United States $v$. Macri ${ }^{57}$ an illegal search and seizure by a federal officer resulted in suppression of evidence, money and paraphernalia, pursuant to a pre-trial motion to suppress relating to violation of the federal excise-wagering tax laws, but the court refused to return the property pending a civil forfeiture or libel action pursuant to section 7302 of the Internal Revenue Code.

It is apparent from the foregoing decisions that the fourth amendment does not assure a return of the property subject to forfeiture.

\section{B. Forfeiture Proceedings as Affected by Acquittal}

Practically every state in the Union has enacted legislation authorizing courts and prosecution officials to confiscate contraband articles, i.e., gambling paraphernalia, narcotics and illicit liquors. The federal government likewise has caused similar laws to be enacted. ${ }^{58}$ Where governmental or state agencies seek to forfeit property or contraband articles, which may have been the subject of criminal charges against a defendant wherein the defendant was acquitted,

\footnotetext{
"Welsh v. United States, 220 F.2d 200 (D.C. Cir. 1955) (money illegally seized in lottery raid and suppressed as evidence held subject to federal tax lien).

5. United States v. Jeffers, 342 U.S. 48 (1951); Trupiano v. United States, 394 U.S. 699 (1948) (contraband distilling equipment illegally seized in violation of Internal Revenue laws properly suppressed as evidence in criminal proceeding but owner not entitled to its return inasmuch as it was contraband); Carroll v. United States, 267 U.S. 132 (1925) (alcohol).

ss 263 F.2d 758 (5th Cir.), cert. denied, 360 U.S. 918 (1959) (illegally seized evidence held subject to federal tax liens and levy).

so 286 F.2d 841 (2d Cir.), cert. denied, 366 U.S. 944 (1961) (money received in search not ordered returned where tax lien had been asserted).

${ }^{\circ 7} 185$ F. Supp. 144 (D. Conn. 1960).

${ }^{59}$ See $\S \S 7301-44$, INT. REv. CodE OF 1954; 18 U.S.C. §3615 (1958).
} 
what effect does the acquittal of the accused have upon such forfeiture proceeding?

It was early held in Coffey $v$. United States that where the same acts that are relied upon to justify the forfeiture have already been determined and adjudicated in the criminal prosecution, the acquittal of the defendant operates as a bar to the forfeiture proceeding ${ }^{59}$ The Coffey decision was followed recently in United States $v$. One 1956 Ford Fairlane Tudor Sedan..$^{00}$

The observation has been made, however, that the statutory provisions defining a criminal offense and the statutory provisions providing for a forfeiture and confiscation of contraband articles are separate and apart and should be determined in independent causes of action. ${ }^{61}$ The reasoning behind this view is that the degree of proof required in each instance is different. Thus, not every acquittal in a criminal case will operate as a bar to forfeiture proceedings, because the facts and circumstances in each case differ inasmuch as the parties may not be the same, or the degree of proof may be different. In the landmark case of Helvering $v$. Mitchell, ${ }^{\text {, }}$ the accused was criminally charged for willful tax evasion in violation of the Internal Revenue Code and acquitted, and the government then sought to impose a civil tax fraud penalty upon the accused who defended on the ground that he had been acquitted of criminal charges touching on the same subject matter. The Supreme Court of the United States rejected this contention maintaining that the accused could have been acquitted because of the degree of proof that the government was required to adduce in order to obtain conviction; whereas, on the civil side of the case, a lesser degree of proof could well establish the fact that the accused was amenable to a civil tax penalty. The Supreme Court in Mitchell distinguished Coffey which was held not to apply to a situation where there had been an acquittal upon a criminal case followed by a civil action requiring a different degree of proof.

While mere acquittal in the criminal action is not an adjudica-

\footnotetext{
${ }^{60}$ Coffey v. United States, 116 U.S. 436 (1886) (forfeiture of spirits and distilling equipment barred by acquittal on charge of removing and concealing distilled spirits with the intent to defraud the revenue).

${ }^{\circ 0} 272$ F.2d 704 (10th Cir. 1959) (held acquittal in criminal case barred Government recovery in subsequent forfeiture suit for automobile where based on same set of facts).

oI United States v. Harvin, 91 F. Supp. 249 (E.D. Va. 1950) (conviction or acquittal of criminal offense of possessing liquor intended for use in violating Internal Revenue laws does not bar forfeiture).

¿2 303 U.S. 391 (1938).
} 
tion upon which the owner can rely in the forfeiture action, ${ }^{63}$ evidence suppressed because of the illegal search has been ruled inadmissible in the civil forfeiture proceeding. ${ }^{64}$ The forfeiture action, moreover, is insufficient if, absent the suppressed evidence, the record lacks in evidence to support the forfeiture. ${ }^{65}$

A review of the foregoing indicates that the better view is that acquittal of the criminal charge does not bear on the civil forfeiture proceeding; that illegally obtained evidence suppressed in the criminal case appears not admissible in the civil forfeiture case; and that the fourth amendment does not insure the return of contraband or property forfeitable or subject to lien or libel.

IV

\section{Conclusion}

It is seen that the role played by the fourth amendment has undergone radical expansion in the criminal area of the law and that the fourth amendment plays a definite role in certain civil proceedings. The ability of the Internal Revenue Service to investigate is essential to the proper determination, assessment and collection of taxes and an investigative civil summons has been likened unto a grand jury subpoena and equivalent to a search and seizure. Prior to an investigation of barred years, the government generally has been required to show a probability of fraud or at least a suspicion of fraud on either section 7605 (b) codal grounds or constitutional grounds under the fourth amendment. Under certain narrow circumstances, the fourth amendment apparently may also be utilized to render invalid a civil tax assessment. The fourth amendment does not guarantee a return of forfeited property and the forfeiture proceedings seem not to be affected by an acquittal. It may reasonably be anticipated that the fourth amendment's role in civil cases will undergo further expansion in the future. ${ }^{86}$

${ }^{03}$ United States v. Physic, 175 F.2d 398 (2d Cir. 1949); United States v. One 1953 Oldsmobile Sedan, 132 F. Supp. 14 (W.D. Ark. 1955); United States v. 38 Cases, 99 F. Supp. 460 (S.D.N.Y. I95I); State v. Dubose, 152 Fla. 304, 11 So. 2d 477 (1943).

of United States v. Physic, supra note 63; United States v. One 1953 Oldsmobile Sedan, supra note 63.

of United States v. Physic, 175 F.2d 338 (2d Cir. 1949).

${ }^{\circ}$ Note the recent decision in Peters v. Rosetti (N.Y. City Civ. Ct.), 31 U.S.I. WEEK 2396 (Feb. 1, 1963), wherein the court, relying on Mapp v. Ohio, 367 U.S. 643 (I961), ruled that evidence obtained by police officers from an apartment during an illegal search was inadmissable in a civil suit where the tenant of the apartment sought to recover money taken from him in the search. 